\title{
PENGARUH TOTAL QUALITY MANAGEMENT (TQM) TERHADAP KINERJA KARYAWAN DENGAN MEDIASI KEPUASAN KERJA
}

(Studi Pada Bagian Produksi Pabrik Kertas PT. Setia Kawan Makmur Sejahtera Tulungagung)

\author{
Desy Eka Kartika Sari ${ }^{1}$, Surachman $^{2}$, Kusuma Ratnawati ${ }^{3}$ \\ Magister Manajemen Fakultas Ekonomi dan Bisnis Universitas Brawijaya ${ }^{123}$ \\ Email: desyekakartikasari9820@gmail.com
}

\begin{abstract}
This study analyzes both of directly effects between implementation of Total Quality Management (TQM) on employee's performance and indirectly effect through job satisfaction. Subjects of this study were all the employees sited on production department of PT. Setia Kawan Makmur Sejahtera Tulungagung. The sampling technique used is the simple random sampling with 152 respondents. Model analysis used is a structural model with the Partial Least Square (PLS). The result of this study reveal that the improving of TQM practices would led to increased both of employee's job satisfaction and employee's performance directly. Then, the higher of job satisfaction can also enhance the employee's performance directly. The mediation test result show that job satisfaction have partial mediationg role in effect of TQM practices on employee's performance. Moreover, the overall results implies that teamwork is the most important aspect in building a good relations among employees, so as to encourage the employee's job satisfaction and ultimately improve the quality of employee's performance.
\end{abstract}

\section{Keywords: Employee's Performance, Job Satisfaction, Total Quality Management (TQM)}

\begin{abstract}
Abstrak : Tujuan penelitian ini adalah untuk menguji dan menganalisis pengaruh Total Quality Management (TQM) terhadap kinerja karyawan dengan mediasi kepuasan kerja pada PT. Setia Kawan Makmur Sejahtera Tulungagung. Teknik pengambilan sampel yang digunakan adalah simple random sampling sebanyak 152 responden. Model analisis yang digunakan untuk mengetahui pengaruh antar variabel adalah model struktural dengan pendekatan Partial Least Square (PLS). Hasil penelitian menunjukkan bahwa implementasi praktik TQM dapat meningkatkan baik kepuasan kerja karyawan maupun kinerja karyawan secara langsung. Kemudian kepuasan yang dirasakan karyawan juga dapat meningkatkan kinerja karyawan secara langsung. Hasil pengujian mediasi menunjukkan bahwa kepuasan kerja memberikan pera mediasi sebagian (partial mediation) pada pengaruh praktik TQM terhadap kinerja karyawan.
\end{abstract}

Kata Kunci: Kepuasan Kerja, Kinerja Karyawan, Total Quality Management (TQM) 


\section{Pendahuluan}

Manajemen operasi dalam sebuah organisasi memiliki peran penting untuk menciptakan profitabilitas dan keberlanjutan (Ozduru, 2015). Dalam konteks strategi perusahaan, penerapan manajemen operasi ditujukan untuk meningkatkan produktivitas melalui peningkatan nilai tambah dari produk dan jasa yang dihasilkan dalam setiap proses produksi, sehingga bisa menghasilkan kinerja perusahaan yang optimal (Milovanovic, 2016). Salah satu upaya yang dapat dilakukan oleh perusahaan dalam meningkatkan produktivitasnya adalah melalui pengelolaan sumber daya secara tepat, sehingga bisa menghasilkan output (barang dan jasa) dengan kualitas yang tepat, dalam jumlah yang tepat, dalam jangka waktu yang tepat, dan dengan biaya yang tepat (Akrani, 2011).

TQM merupakan sebuah konsep yang digunakan oleh organisasi untuk mempertahankan keunggulan bersaing dan memastikan efektivitas operasional perusahaan (Al Nasser, et al. 2013; Chang, et al. 2010). Penerapan TQM dilakukan sebagai salah satu strategi perusahaan dalam menghasilkan kinerja pelayanan yang baik, sehingga pelaksanaannya berorientasi pada kepuasan pelanggan dan melibatkan seluruh anggota perusahaan termasuk karyawan (Poernomo, 2006). Dari sini, dapat dikatakan bahwa praktik TQM ditujukan untuk melakukan perbaikan secara berkesinambungan (terus-menerus) terhadap produk atau jasa, sumber daya manusia, proses dan lingkungannya (Putri, 2009), sehingga bisa menghasilkan kualitas yang terbaik dan unggul dalam persaingan (Tjiptono dan Diana, 2007).

Terkait dengan kinerja karyawan, pada dasarnya penerapan TQM yang dilakukan secara terencana dan terarah diharapkan dapat membantu dalam peningkatan produktivitas dan kinerja karyawan (Poernomo, 2006). Oleh karena itu, perusahaan perlu membuat sistem pengukuran kinerja yang tepat untuk mengetahui karakteristik dan kualitas kinerja serta mengidentifikasi tindakan-tindakan yang dapat diambil dalam upaya meningkatkan produktivitas kerja karyawan. Semakin sering suatu perusahaan melakukan pengukuran kinerja karyawan, maka perusahaan akan lebih meningkatkan kinerja karyawannya, dan peningkatan kinerja tersebut akan berdampak pada peningkatan mutu perusahaan (Ismunawan, 2010).
Secara empiris, hasil kajian mengenai dampak penerapan TQM terhadap kinerja karyawan ditunjukkan oleh Therese (2007) yang menemukan adanya hubungan positif yang kuat antara tingkat pelaksanaan praktik TQM dengan kinerja organisasi. Kemudian Al-Shobaki, et al. (2010) juga telah menemukan bukti bahwa penerapan TQM mampu meningkatkan kinerja organisasi yang tercermin pada efisiensi dan produktivitas. Sebaliknya, hasil temuan Enny (2015) menunjukkan bahwa TQM tidak memiliki pengaruh positif dan signifikan terhadap kinerja karyawan. Dari temuan penelitian tersebut, diketahui bahwa penerapan TQM dapat mempengaruhi kinerja karyawan, meskipun pengaruh tersebut mungkin berbeda pada setiap perusahaan.

Selain bertujuan untuk meningkatkan kinerja organisasi melalui kinerja karyawannya, efektivitas penerapan TQM juga dapat mendorong perasaan afektif seseorang dalam pekerjaannya. Dalam hal ini, TQM sebagai sistem manajemen mutu yang berorientasi pada kualitas produk dan jasa, mempunyai tujuan akhir yakni mencapai kepuasan pelanggan (Samsir, 2014). Seperti yang dinyatakan oleh Akdere (2009) bahwa terdapat hubungan positif yang kuat antara kepuasan pelanggan dan kepuasan kerja karyawan. Hal ini memberikan implikasi bahwa kepuasan pelanggan, sebagai tujuan dari manajemen mutu, dapat dicapai melalui kepuasan kerja karyawan (Schroeder, et al. 2005).

Kepuasan kerja diasumsikan sebagai bentuk reaksi secara emosional atas sebuah pekerjaan yang dilakukan oleh seseorang (Locke, 1969 dalam Carmeli dan Freund, 2004). Secara definitif, kepuasan kerja merupakan keadaan akhir dari proses psikologis (Bernal, et al. 2005), yang mencerminkan sikap umum karyawan terhadap pekerjaannya. Dalam penerapan Total Quality Manajement (TQM), pegawai bekerja dalam kelompok, sehingga hal ini memberikan perasaan puas karyawan untuk bekerja dalam organisasi (Malik, et al. 2013). Selain itu, Ariyanti (2002) juga menjelaskan bahwa melalui penerapan TQM, manajemen perusahaan telah mampu menjelaskan visi dari kualitas secara total, didukung dengan keterlibatan karyawan dan adanya proses pembelajaran yang dapat mendukung manajemen proses. Dengan demikian, dapat dikatakan bahwa pelaksanaan TQM memberikan dampak positif pada organisasi dan karyawannya (Ooi, et al. 2005), sehingga akan 
membawa kepuasan kerja yang lebih tinggi (Yuan, et al. 2011).

PT. Setia Kawan Makmur Sejahtera menerapkan sistem manajemen mutu ISO sebagai komitmen perusahaan untuk menjaga kualitas produknya. Sistem manajemen mutu tersebut diterapkan mulai dari proses awal, yakni pemilihan pemasok, bahan awal, proses produksi, sampai distribusi produk kepada enduser. Sesuai dengan misinya, perusahaan berusaha menyediakan produk yang berkualitas tinggi dan mempunyai kehandalan yang baik. Selain itu, perusahaan telah menerapkan penilaian risiko serta manajemen risiko untuk menjamin kualitas dan keamanan produk yang dihasilkan.

Berdasarkan hasil wawancara yang dilakukan oleh peneliti, diketahui bahwa terdapat beberapa kendala yang dihadapi oleh PT. Setia Kawan Makmur Sejahtera Tulungagung dalam waktu 3 tahun terakhir, khususnya pada bagian produksi. Salah satu kendala yang paling menonjol dibagian produksi yaitu adanya ketidakseimbangan jumlah karyawan yang keluar dan jumlah karyawan yang masuk. Dari data yang diberikan oleh manajer produksi PT. Setia Kawan Makmur, menunjukkan bahwa permasalahan turnover karyawan ini terjadi sekitar tahun 2013 sampai dengan 2015, dengan prosentasi masing-masing sebesar sebesar 3,1\% di tahun 2013, 1,6\% di tahun 2014 dan 2,1\% di tahun 2015 (dari total 245 karyawan). Kondisi ini tentu saja dapat merugikan perusahaan, karena selain menambah posting biaya bagi perusahaan untuk merekrut karyawan baru, juga memberikan implikasi pada terhambatnya operasional perusahaan akibat kekurangan karyawan. Selain itu, kompleksitas pekerjaan juga menjadi lebih tinggi karena pada dasarnya setiap bagian atau saluran yang ada pada perusahaan memiliki keterkaitan satu sama lain, sehingga semua karyawan diharuskan mampu bekerja secara tim untuk meminimalisasi kemungkinan terjadinya kesalahan dalam pekerjaan.

Melihat permasalahan yang terjadi di PT. Setia Kawan Makmur di atas, maka menjadi penting bagi perusahaan untuk lebih concern terhadap karyawannya. Terjadinya masalah ketidakseimbangan antara karyawan yang diterima dan keluar tersebut mencerminkan masih rendahnya tingkat kepuasan kerja yang dirasakan oleh karyawan, yang mungkin diakibatkan oleh beberapa faktor, seperti kerjasama (teamwork) yang belum berjalan secara optimal, kurangnya perencanaan dan evaluasi untuk setiap kegiatan yang dilakukan, seringkali terjadi konflik diantara karyawan, prestasi kerja kurang optimal karena pola pembagian kerja kurang merata, dan kurangnya penghargaan yang dirasakan secara adil, sehingga pada akhirnya akan berdampak pada menurunnya kinerja karyawan. Perusahaan perlu melakukan berbagai upaya untuk mengidentifikasi kebutuhan karyawan serta mendongkrak motivasi dan semangat kerja mereka, sehingga diharapkan dari upaya tersebut nantinya bisa meningkatkan kinerja karyawan, yang artinya juga menurunkan permasalahan turnover karyawan.

Penelitian Ardiansyah (2016), yang sebelumnya telah mengkaji dampak kepuasan kerja terhadap kinerja karyawan PT. Setia Kawan Makmur Sejahtera Tulungagung, dan menemukan bahwa kinerja karyawan di bagian produksi Pabrik Kertas lebih dipengaruhi oleh kepuasan kerja yang mereka rasakan dibandingkan pola komunikasi yang ada, maka peneliti bermaksud untuk mengkaji kembali dalam konteks yang lebih luas, yakni dengan mengkaitkan implementasi praktik TQM yang dijalankan oleh perusahaan terhadap kepuasan kerja dan kinerja karyawan. Dengan mendasarkan kajian pada faktor manusia, diharapkan bisa mengetahui seberapa besar tingkat pencapaian yang dihasilkan oleh perusahaan. Dalam hal ini, kinerja karyawan merupakan salah satu indikator pencapaian hasil perusahaan yang mendukung pencapaian tujuan.

Tulisan ini bermaksud Untuk mengetahui dan menganalisis pengaruh Total Quality Management (TQM) terhadap kepuasan kerja, mengetahui dan menganalisis pengaruh Total Quality Management (TQM) terhadap kinerja karyawan, mengetahui dan menganalisis pengaruh kepuasan kerja terhadap kinerja karyawan, mengetahui dan menganalisis pengaruh Total Quality Management (TQM) terhadap kinerja karyawan yang dimediasi oleh kepuasan kerja. Oleh karena itu, berdasarkan uraian latar belakang diatas, maka dapat dirumuskan permasalahan dalam penelitian ini adalah:

1. Apakah terdapat pengaruh signifikan antara praktik Total Quality Management (TQM) terhadap kepuasan kerja?

2. Apakah terdapat pengaruh signifikan antara praktik Total Quality Manajement (TQM) terhadap kinerja karyawan?

3. Apakah terdapat pengaruh signifikan antara 
kepuasan kerja terhadap kinerja karyawan?

4. Apakah terdapat pengaruh signifikan antara praktik Total Quality Manajement (TQM) terhadap kinerja karyawan dengan mediasi kepuasan kerja?

\section{Total Quality Manajement (TQM)}

Kualitas atau "quality" berasal dari istilah latin yakni "qualitas" yang berarti karakteristik, sifat, fitur. Kualitas dapat ditemukan dengan membandingkan jumlah karakteristik yang melekat dengan kebutuhan atau persyaratan tertentu (Luburic, 2014). Flynn, et al. (1994) menjelaskan bahwa TQM merupakan pendekatan terpadu yang bertujuan untuk mendapatkan serta mempertahankan output berkualitas tinggi, kemudian fokus atas pemeliharaan dan perbaikan berkelanjutan dan pencegahan kegagalan di semua level dan fungsi perusahaan, dalam rangka memenuhi dan atau melampaui harapan konsumen. Di sisi lain, Kaynak (2003) menjelaskan bahwa TQM dapat dipahami sebagai filosofi manajemen holistik yang mendorong perbaikan dan pengembangan kontinyu dalam semua fungsi organisasi, dan dapat diraih jika konsep kualitas total digunakan dari penggunaan sumber daya pada layanan purna jual pelanggan.

Berdasarkan pengertian para ahli di atas, Total Quality Management (TQM) secara garis besar dapat diartikan sebagai strategi dan filosofi manajemen yang mencoba mengintegrasikan semua fungsi organisasi yang melibatkan seluruh manajer dan karyawan untuk saling bekerja sama di dalam meningkatkan produk, jasa, manusia, proses, dan lingkungan sehingga dapat mengoptimalkan kinerja karyawan dari perusahaan tersebut.

\section{Kepuasan Kerja}

Kepuasan kerja telah menjadi salah satu tujuan utama perusahaan dalam beberapa tahun terakhir. Organisasi tidak dapat mencapai tingkat kualitas yang kompetitif, terutama pada tingkatan kinerja, jika personil mereka tidak merasa puas atau tidak mampu mengidentifikasi dirinya dengan perusahaan. Garcia-Bernal, et al. (2005) menjelaskan konsep kepuasan sebagai "ringkasan dan respon afektif atas intensitas hal yang berpusat pada aspek tertentu dari akuisisi dan atau konsumsi, serta yang terjadi pada saat yang tepat ketika seorang individu mengevaluasi suatu objek". Berbagai usaha telah dilakukan oleh para peneliti dalam menentukan konsep kepuasan yang baku dan disepakati bersama, serta terdapat pengakuan secara umum bahwa kepuasan adalah keadaan akhir dari sebuah proses psikologis yang dialami oleh individu.

\section{Kinerja Karyawan}

Kinerja dalam bahasa Inggris disebut performance, yang dapat diartikan dengan pekerjaan, perbuatan atau penampilan. Kinerja mempunyai makna yang lebih luas, bukan hanya menyatakan hasil kerja, tetapi bagaimana proses kerja berlangsung. Kinerja adalah tentang apa yang dikerjakan dan bagaimana hasil yang dicapai dari pekerjaan tersebut. Kinerja dalam pekerjaan berasal dari kata job performance atau actual performance (prestasi kerja atau prestasi sesungguhnya yang dicapai oleh seseorang). Kinerja seseorang merupakan kombinasi dari kemampuan, usaha dan kesempatan yang dapat dinilai dari hasil kerjanya. Kinerja merupakan catatan outcome yang dihasilkan dari fungsi individu tertentu atau kegiatan yang dilakukan selama periode waktu tertentu.

Gordon (2005) menjelaskan definisi kinerja sebagai kemampuan seseorang dipengaruhi oleh bakat dan minat, sedangkan usaha dipengaruhi motivasi, insentif, dan rancangan pekerjaan serta yang masuk dukungan organisasi adalah mencakup pelatihan pengembangan sumberdaya manusia dan tersedianya peralatan organisasi. Mangkunegara (2012) mengemukakan definisi kinerja (prestasi kerja) sebagai hasil kerja secara kualitas dan kuantitas yang dicapai oleh seorang pegawai dalam melaksanakan tugasnya sesuai dengan tanggung jawab yang diberikan kepadanya. Hasibuan (2011) mengemukakan bahwa prestasi kinerja adalah suatu hasil kerja yang dicapai seseorang dalam melaksanakan tugas-tugas yang dibebankan kepadanya yang didasarkan atas kecakapan, pengalaman dan kesungguhan, serta waktu. Prestasi kerja merupakan gabungan dari tiga faktor penting, yaitu kemampuan dan minat seorang pekerja, kemampuan dan penerimaan atas penjelasan delegasi tugas, serta peran dan tingkat motivasi seorang pekerja. Semakin tinggi ketiga faktor di atas, semakin besar prestasi kerja karyawan yang bersangkutan. Kinerja diartikan sebagai kesuksesan yang dicapai seseorang melaksanakan suatu pekerjaan. Kesuksesan yang dimaksud tersebut ukurannya tidak dapat disamakan pada semua orang, namun lebih merupakan hasil yang dicapai oleh seseorang menurut ukuran yang berlaku sesuai dengan pekerjaan yang ditekuninya. 
Berdasarkan beberapa pendapat para ahli di atas, maka dapat disimpulkan bahwa kinerja adalah suatu hasil kerja yang dicapai seseorang dalam melaksanakan penugasan yang dibebankan kepadanya, baik secara kualitas maupun kuantitas yang dilakukan selama periode waktu tertentu.

\section{Kerangka Konsep Penelitian}

Sebagaimana telah dijelaskan pada bab sebelumnya, bahwa tujuan penerapan manajemen operasi sebagai salah satu implementasi strategis perusahaan adalah untuk mencapai kinerja perusahaan yang optimal (Milovanovic, 2016). Pencapaian kinerja perusahaan bisa ditingkatkan melalui peningkatan produktivitas perusahaan. Salah satu upaya yang dapat dilakukan perusahaan dalam meningkatkan produktivitasnya adalah melalui pengelolaan sumber daya secara tepat (Akrani, 2011), yang dalam hal ini sumber daya manusia dianggap sebagai sumber daya paling penting dan aset paling berharga (Shah, et al. 2012), sehingga mendorong perusahaan untuk lebih fokus pada aspek perencanaan dan pengendalian pada faktor manusia (Ismunawan, 2010).

Crossman dan Abou-Zaki (2003) menyatakan bahwa efektivitas organisasi sangat tergantung pada sumber daya manusia yang mereka miliki. Dalam konteks tersebut, peran sumber daya manusia bisa dilihat dari kualitas kerjasama tim diantara para karyawan, sehingga apabila mereka mendapatkan dukungan organisasi yang tinggi dalam pekerjaannya maka organisasi akan dapat berkembang (Dessler, 2008). Lebih lanjut, Dessler (2008) juga menjelaskan bahwa tim karyawan yang termotivasi dengan baik akan membantu pencapaian target organisasi. Semakin besar partisipasi dari karyawan dapat memberikan pengaruh pada kinerja organisasi dan kesejahteraan karyawan itu sendiri (Humphrey, et al. 2007). Dengan demikian, dapat dikatakan bahwa kinerja perusahaan dapat tercapai melalui kinerja karyawannya.

Kinerja diasumsikan sebagai hasil dari fungsi pekerjaan pada organisasi dalam periode waktu tertentu (Tika, 2006). Tinggi rendahnya kinerja organisasi tergantung pada tinggi rendahnya kinerja individu (Aydin, et al. 2010). Dari sini, sangat penting bagi perusahaan untuk menggunakan sistem manajemen yang baik, yang dapat dijadikan sebagai alat untuk meningkatkan kinerja perusahaan melalui kinerja karyawannya (Alhudri dan Heriyanto, 2015). Salah satu sistem manajemen kualitas yang banyak digunakan adalah Total Quality Management (TQM). Konsep TQM merupakan suatu pendekatan manajemen yang difokuskan pada perbaikan kualitas produk atau jasa, sumber daya manusia, proses dan lingkungannya secara berkesinambungan (Putri, 2009). Implementasi efektif dari TQM dapat mendorong, baik dalam pengembangan kinerja organisasional (Prajogo dan Sohal, 2006), maupun peningkatan produktivitas dan kinerja karyawan (Poernomo, 2006).

Dampak implementasi TQM terhadap kinerja karyawan telah dikaji sebelumnya oleh Therese (2007); Al-Shobaki, et al. (2010); Zehir (2010); Sukwadi (2012); dan Tinuke, et al. (2012) yang telah menemukan bahwa praktik TQM mempunyai hubungan dan pengaruh yang kuat terhadap kinerja karyawan. Di sisi lain, hasil kajian Enny (2015) menunjukkan temuan yang sebaliknya yakni praktik TQM tidak mempunyai pengaruh yang kuat terhadap kinerja karyawan.

Perbaikan sistem manajemen mutu organisasi merupakan faktor yang dapat berpengaruh terhadap pencapaian peningkatan kepuasan kerja pegawai (Juana, et al. 2016). Sedangkan kepuasan kerja itu sendiri diasumsikan sebagai perasaan bangga dan kepuasan internal yang dirasakan karyawan saat melakukan tugas yang spesifik (Saleem, 2015). Dalam pelaksanaan perbaikan sistem manajemen mutu organisasi, diperlukan adanya perubahan organisasi, yang hal ini menuntut peran yang berbeda dari kedua belah pihak yakni organisasi dan karyawan (Grunberg, et al. 2001). Setiap karyawan mungkin akan bereaksi dengan cara yang berbeda terhadap perubahan alat-alat organisasional tersebut, yakni di satu sisi beberapa karyawan mungkin akan melihat perubahan sebagai kesempatan untuk pengembangan diri yang pada gilirannya akan meningkatkan kepuasan kerja mereka, namun di sisi lain beberapa karyawan lainnya mungkin menolak bahkan untuk perubahan kecil sekalipun (Barger dan Kirby, 1995 dalam Yue, et al. 2011). Akibatnya, pelaksanaan TQM kemungkinan akan mempengaruhi hasil pekerjaan karyawan, terutama yang berhubungan dengan kepuasan kerja karyawan.

Sebagaimana dinyatakan oleh Kabak, et al. (2014) bahwa kepuasan kerja bukan merupakan fenomena konstan, akan tetapi bisa berubah sesuai dengan perubahan eksternal (perubahan 
organisasi) atau perubahan internal dalam sikap atau perilaku karyawan. Pernyataan tersebut sejalan dengan temuan beberapa penelitian sebelumnya yang menunjukkan hasil yang tidak konsisten, yakni Taib, et al. (2010); Valmc ${ }^{-}$adi dan Khodapanahi (2011); Alsugl - et al. (2014); dan Juana, et al. (2016) yang telah menemukan adanya hubungan dan pengaruh yang positif dan signifikan antara implementasi praktik TQM dengan kepuasan kerja karyawan. Sebaliknya Vidal (2007) telah menemukan adanya pengaruh negatif antara praktik TQM dengan kepuasan kerja, serta Menezes (2013) tidak menemukan adanya hubungan yang signifikan antara manajemen mutu perusahaan dengan kepuasan kerja karyawan.

Kepuasan kerja dipandang sebagai rute potensi untuk pencapaian kinerja yang tinggi (Wright, et al. 2003) dan sebagai mediator potensial dalam rantai hipotetis dari praktik manajemen kinerja (Purcell dan Kinnie, 2007). Kepuasan kerja mendorong karyawan untuk lebih meningkatkan prestasi kerjanya, dan kemudian membuat mereka bekerja lebih keras dan lebih baik (Pushpakumari, 2008). Dengan demikian, karyawan yang puas dengan pekerjaan mereka cenderung lebih berkomitmen untuk organisasi dan lebih produktif (Hsu dan Wang, 2008).

Kepuasan kerja karyawan merupakan tujuan penting bagi organisasi untuk mencapai kinerja dan efisiensi yang lebih baik (SousaPouza dan Sousa-Pouza, 2000). Kepuasan kerja dan kinerja dapat menjadikan produktivitas karyawan lebih tinggi, sehingga hal ini menjadi tujuan prioritas organisasi (Dizgah, 2012). Pernyataan-pernyatan tersebut secara empiris didukung oleh hasil temuan beberapa penelitian sebelumnya, seperti Syaiin (2008); Nimalathasan (2012); Vromm dalam Dizgah (2012) yang telah menemukan adanya hubungan dan pengaruh yang kuat antara kepuasan kerja dengan kinerja karyawan.

Dari uraian di atas, diketahui bahwa terdapat determinan yang dapat menjelaskan pola hubungan antara TQM, kepuasan kerja, dan kinerja karyawan. Kemudian bertitik tolak dari latar belakang, rumusan masalah, dan tinjauan pustaka baik secara teori maupun secara empiris, maka penelitian ini berusaha mengembangkan dan mengkaji kembali model yang lebih luas mengenai pengaruh penerapan praktik TQM terhadap kinerja karyawan dengan kepuasan kerja sebagai mediasi.
Kerangka konseptual dalam penelitian ini ditunjukkan pada Gambar 3.1.

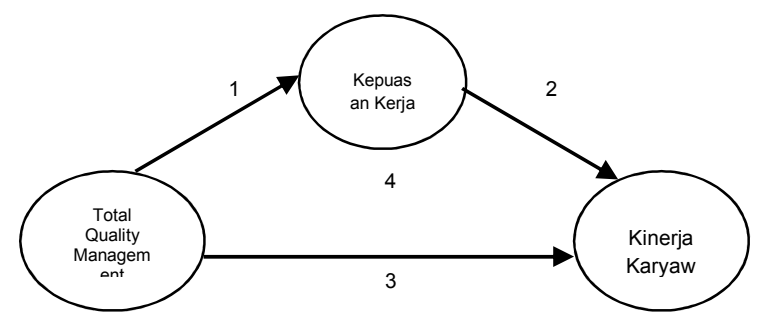

Kerangka Konseptual Penelitian

\section{Hipotesis Penelitian}

H1:Terdapat Pengaruh Total Quality Manajement (TQM) dengan kepuasan kerja

H2: Terdapat pengaruh signifikan antara kepuasan kerja terhadap kinerja karyawan.

H3: Terdapat pengaruh signifikan antara TQM terhadap kinerja karyawan..

$\mathrm{H} 4$ : terdapat pengaruh signifikan antara TQM terhadap kinerja karyawan yang dimediasi oleh kepuasan kerja.

\section{Metode Penelitian \\ Jenis Penelitian}

Berdasarkan rumusan masalah dan tujuan penelitian, maka jenis penelitian ini bersifat explanatory. Penelitian explanatory merupakan penelitian yang bermaksud menjelaskan kedudukan variabel-variabel yang diteliti serta hubungan dan pengaruh antara satu variabel dengan variabel lain (Sugiyono, 2011). Dari sini, penelitian explanatory menjelaskan hubungan kausal antara satu variabel dengan variabel lainnya melalui pengujian hipotesis.

\section{Lokasi Penelitian}

Penelitian ini dilakukan di PT. Setia Kawan Makmur Sejahtera Tulungagung yang merupakan perusahaan manufaktur yang bergerak di bidang produksi kertas. Lokasi kantor pusat dan pabrik berada di satu tempat, yakni beralamatkan di Desa Tapan, Kecamatan Kedungwaru, Kabupaten Tulungagung, Jawa Timur.

\section{Populasi Dan Sampel}

Populasi yang digunakan dalam penelitian ini adalah karyawan bagian produksi Pabrik Kertas PT. Setia Kawan Makmur Sejahtera Tulungagung yang berjumlah 245 orang (Sumber: Data statistik tahunan perusahaan PT. Setia Kawan Makmur Sejahtera Tulungagung).

Teknik Metode sampel yang digunakan dalam penelitian ini adalah probability 
sampling, sedangkan teknik pengambilan sampel yang digunakan adalah simple random sampling. Pemilihan teknik ini didasarkan pada penyebaran anggota populasi yang tidak terlalu luas secara geografis dan karakteristik populasi yang cukup homogen, yang secara keseluruhan diambil melalui unit yang sama yaitu divisi produksi PT. Setia Kawan Makmur Sejahtera Tulungagung.

Berdasarkan jumlah populasi sebanyak 245 orang, maka untuk menentukan besarnya sampel penelitian dilakukan dengan menggunakan rumus Yamane, dengan tujuan untuk mendapatkan sampel yang representative dan lebih pasti atau mendekati populasi yang ada. Rumus Yamane yang digunakan adalah sebagai berikut:

$$
\begin{aligned}
\mathrm{n} & =\frac{\mathrm{N}}{1+\mathrm{Ne}^{2}} \\
& =\frac{245}{1+245(0.05)^{2}} \\
& =151,94
\end{aligned}
$$

Keterangan:

n : Jumlah sampel

$\mathrm{N} \quad$ : Jumlah populasi

e : Presisi 5\% dengan tingkat kepercayaan $95 \%$

Dari perhitungan sampel di atas, diketahui bahwa jumlah sampel dalam penelitian ini adalah sebesar 151,94 atau 152 orang pada tingkat kepercayaan $95 \%$.

\section{Metode Analisis Data}

Dalam penelitian ini analisis data menggunakan pendekatan Partial Least Square (PLS). PLS adalah model persamaan Structural Equation Modeling (SEM) yang berbasis komponen atau varian. Menurut Ghozali (2006), PLS merupakan pendekatan alternatif yang bergeser dari pendekatan SEM berbasis kovarian menjadi berbasis varian. Evaluasi model dalam PLS dilakukan dengan melakukan evaluasi pada outer model dan inner model. Outer model merupakan model pengukuran untuk menilai validitas dan reliabilitas model (Hartono dan Abdillah, 2009). Inner model merupakan model struktural untuk menilai hubungan antara konstruk atau variabel laten.

\section{Hasil Penelitian}

Pengujian hipotesis dalam analisis PLS (Partial Least Square) bisa dilakukan dengan melihat hasil nilai uji t-statistik maupun nilai probabilitasnya. Hipotesis bisa diterima apabila nilai probabilitasnya kurang dari 0,05 (tingkat signifikansi 0,05$)$ atau nilai t-statistic lebih besar dari t-tabel $(1,96)$.

Hasil pengujian data melalui path analysis ditunjukkan pada tabel di bawah ini.

\section{Hasil Path Analysis}

\begin{tabular}{|l|c|c|c|c|}
\hline $\begin{array}{c}\text { Hubungan } \\
\text { Antar } \\
\text { Konstruk }\end{array}$ & $\begin{array}{c}\text { Koefisien } \\
\text { Jalur }\end{array}$ & t-Statistic & $\begin{array}{c}\text { Cut- } \\
\text { off }\end{array}$ & Keterangan \\
\hline $\begin{array}{l}\text { TQM -> } \\
\text { Kepuasan } \\
\text { Kerja }\end{array}$ & 0,805 & 27,5176 & 1,96 & Signifikan \\
\hline $\begin{array}{l}\text { TQM -> } \\
\text { Kinerja } \\
\text { Karyawan }\end{array}$ & 0,772 & 16,8728 & 1,96 & Signifikan \\
\hline $\begin{array}{l}\text { Kepuasan } \\
\text { Kerja -> } \\
\text { Kinerja } \\
\text { Karyawan }\end{array}$ & 0,398 & 3,7983 & 1,96 & Signifikan \\
\hline
\end{tabular}

Sumber: Data primer diolah, 2016

Berdasarkan data pada Tabel di atas, maka hasil pengujian hipotesis dapat dijelaskan sebagai berikut:

\section{H1: Terdapat pengaruh signifikan antara Total Quality Manajement (TQM) terhadap Kepuasan Kerja}

Berdasarkan hasil diketahui bahwa pengaruh TQM terhadap kepuasan kerja memiliki nilai t-statistik lebih besar dari nilai ttabel $(27,5176>1.96)$. Dapat disimpulkan bahwa variabel Total Quality Manajement (TQM) mempunyai pengaruh signifikan terhadap kepuasan kerja. Dengan demikian, secara statistik hipotesis 1 dapat dinyatakan diterima.

Lebih lanjut, bisa dilihat bahwa pengaruh tersebut bersifat positif (koefisien jalur positif sebesar 0,805), yang artinya semakin baik penerapan praktik TQM akan meningkatkan kepuasan kerja karyawan PT. Setia Kawan Makmur Sejahtera Tulungagung.

\section{H2: Terdapat pengaruh signifikan antara kepuasan kerja terhadap kinerja karyawan}

Pengaruh kepuasan kerja terhadap kinerja karyawan ditunjukkan oleh hasil analisis dan diketahui bahwa nilai t-statistik lebih besar dari nilai t-tabel $(3,7983>1.96)$. Dapat disimpulkan bahwa variabel kepuasan kerja mempunyai pengaruh signifikan terhadap kinerja karyawan. Dengan demikian, secara statistik hipotesis 2 dapat dinyatakan diterima.

Lebih lanjut, hasil analisis juga menunjukkan bahwa pengaruh tersebut bersifat positif (koefisien jalur positif sebesar 0,398), 
yang artinya semakin tinggi tingkat kepuasan kerja akan meningkatkan kinerja karyawan PT. Setia Kawan Makmur Sejahtera Tulungagung.

\section{H3: Terdapat pengaruh signifikan antara TQM terhadap kinerja karyawan}

Hasil analisis pada Tabel di atas menunjukkan bahwa pengaruh TQM terhadap kinerja karyawan memiliki nilai t-statistik lebih besar dari nilai t-tabel $(16,8728>1.96)$. Dapat disimpulkan bahwa variabel Total Quality Manajement (TQM) mempunyai pengaruh signifikan terhadap kinerja karyawan. Dengan demikian, secara statistik hipotesis 3 dapat dinyatakan diterima.

Lebih lanjut, bisa dilihat bahwa pengaruh tersebut bersifat positif (koefisien jalur positif sebesar 0,772), yang artinya semakin baik penerapan praktik TQM akan meningkatkan kinerja karyawan PT. Setia Kawan Makmur Sejahtera Tulungagung.

\section{H4: TQM berpengaruh terhadap kinerja karyawan dengan dimediasi oleh kepuasan kerja}

Pengujian hipotesis yang keempat bertujuan untuk melihat peran mediasi kepuasan kerja pada pengaruh TQM terhadap kinerja karyawan. Seperti yang dijelaskan sebelumnya bahwa pengaruh langsung pada masing-masing jalur hubungan (pengujian hipotesis 1, 2, dan 3) menunjukkan hasil yang signifikan. Selain itu, dari hasil uji mediasi juga diketahui bahwa kepuasan kerja memberikan peran mediasi sebagian (partial mediation) pada pengaruh TQM terhadap kinerja karyawan. Dengan demikian, hipotesis 4 yang menyatakan bahwa TQM berpengaruh terhadap kinerja karyawan dengan dimediasi oleh kepuasan kerja dinyatakan diterima.

\section{Pengaruh Total Quality Manajement (TQM) terhadap kepuasan kerja}

Hasil penelitian menunjukkan bahwa praktik TQM mempunyai dampak penting terhadap kepuasan kerja karyawan PT. Setia Kawan Makmur Sejahtera Tulungagung. Dapat diartikan bahwa semakin baik penerapan praktik TQM yang dijalankan oleh perusahaan akan meningkatkan perasaan puas karyawan PT. Setia Kawan Makmur Sejahtera Tulungagung atas pekerjaannya.

Dari hasil temuan penelitian, diketahui bahwa penerapan TQM pada PT. Setia Kawan Makmur Sejahtera Tulungagung sudah cukup baik, sehingga mampu menciptakan kepuasan kerja karyawannya. Dampak tersebut dapat dilihat, baik melalui kondisi riil yang dirasakan oleh karyawan maupun melalui persepsi atau pemikiran karyawan. Berdasarkan kondisi yang terjadi di perusahaan, implementasi TQM yang diterapkan oleh perusahaan sebenarnya lebih banyak difokuskan pada pelanggan. Perusahaan telah menjalankan berbagai program strategis yang tidak hanya ditujukan sebagai upaya pemenuhan kebutuhan pelanggan, namun juga untuk meningkatkan kualitas produk yang dihasilkan dengan harga yang terjangkau, sehingga dalam jangka panjang bisa meningkatkan keunggulan kompetitif dan memperluas pangsa pasar perusahaan. Tercapainya tujuan perusahaan tersebut telah memberikan feedback pada semua pihak yang terkait, termasuk juga karyawan, yang secara riil lebih banyak dirasakan dari adanya kesempatan promosi yang diberikan oleh perusahaan, sehingga hal ini mendorong perasaan puas karyawan terhadap pekerjaannya.

Sebaliknya, berdasarkan persepsi atau pemikiran karyawan, implementasi TQM yang diterapkan oleh perusahaan akan berhasil atau berjalan efektif apabila perusahaan mampu menciptakan kerjasama yang solid antar masingmasing tim kerja. Kerja sama antar tim dapat memfasilitasi kemampuan pekerja produksi untuk bekerja bersama-sama dalam setiap pekerjaan yang mereka lakukan (Karia dan Asaari, 2006; Ooi, et al. 2007). Selain itu, bekerja sebagai tim juga akan mengarahkan karyawan ke sikap yang lebih baik (Chin dan Saudah, 2011). Meskipun karyawan secara alami mempunyai kepedulian tentang kualitas pekerjaan yang mereka lakukan dan akan mengambil inisiatif untuk memperbaikinya, namun mereka membutuhkan hal lain selain alat dan pelatihan yang diperlukan untuk peningkatan kualitas, yakni tentang kerjasama dalam satu tim. Dalam hal ini, tim yang dimaksud tidak hanya melibatkan sesama karyawan, namun juga antara karyawan dan atasan. Tercapainya solidaritas antar tim tersebut sangat bergantung pada efektivitas fungsi komunikasi dan koordinasi, oleh karenanya sangat dibutuhkan peran supervisi dari seorang atasan. Sebagaimana diketahui bahwa para atasan telah memberikan supervisi yang baik atas setiap pekerjaan, serta berusaha melibatkan karyawan dalam setiap perencanaan dan pelaksanaan kegiatan perusahaan, sehingga dari sini karyawan dapat merasakan puas atas 
pekerjaan yang mereka lakukan.

\section{Pengaruh Kepuasan Kerja terhadap Kinerja Karyawan}

Hasil penelitian menunjukkan bahwa kepuasan kerja mempunyai dampak penting terhadap pencapaian kinerja karyawan. Dapat diartikan bahwa semakin tinggi tingkat kepuasan kerja yang dirasakan oleh karyawan PT. Setia Kawan Makmur Sejahtera Tulungagung akan mendorong peningkatan kinerja mereka.

Pada penelitian ini, kemampuan supervisi seorang atasan (manajer) dinilai sebagai parameter penting dalam menciptakan kepuasan kerja karyawan. Kondisi ini menyiratkan bahwa karyawan akan merasakan puas dalam bekerja ketika mereka memiliki atasan yang suportif dan kooperatif seperti yang mereka inginkan. Di sisi lain, kinerja karyawan lebih banyak ditunjukkan oleh kualitas hasil kerja mereka. Dengan demikian, dapat dikatakan bahwa karyawan PT. Setia Kawan Makmur Sejahtera lebih mengutamakan kualitas hasil dalam penyelesaian pekerjaan mereka.

Berdasarkan hasil temuan penelitian diketahui bahwa kepuasan kerja yang dirasakan oleh karyawan PT. Setia Kawan Makmur Sejahtera Tulungagung dapat mendorong peningkatkan kinerja karyawan tersebut. Temuan ini sangat menarik karena berdasarkan persepsi atau pemikiran yang tertanam di benak karyawan, perasaan puas karyawan terhadap pekerjaan sangat ditentukan oleh supervisi yang diberikan oleh atasan mereka. Dari kepuasan kerja tersebut akan memberikan implikasi pada tingkat kinerja yang dihasilkan oleh karyawan, khususnya terkait dengan kualitas hasil pekerjaan mereka. Dari sini, dapat dikatakan bahwa tingkat produktivitas dan kinerja seorang karyawan dapat didorong melalui tindakan supervisi yang baik. Hal ini sejalan dengan pendapat Brunetto dan Farr-Wharton (2002) yang mengungkapkan bahwa pengawasan secara langsung oleh manajer dapat meningkatkan kepuasan kerja karyawan, dan organisasi yang memiliki karyawan yang lebih puas cenderung lebih efektif dibandingkan organisasi yang memiliki karyawan yang kurang puas (Sousa-Poza and SousaPoza, 2000).

Di sisi lain, berdasarkan kondisi riil yang dirasakan oleh karyawan, perasaan puas terhadap pekerjaan justru mereka peroleh dari kesempatan promosi yang diberikan oleh perusahaan. Dengan adanya program promosi jabatan ini, karyawan menjadi lebih termotivasi dan semakin semangat untuk meningkatkan kinerjanya, yang dalam hal ini lebih banyak ditunjukkan oleh pencapaian kualitas hasil kerja yang tinggi.

\section{Pengaruh Total Quality Manajement (TQM) terhadap kinerja karyawan}

Hasil temuan pada penelitian ini menunjukkan bahwa penerapan praktik TQM memberikan dampak penting terhadap kinerja karyawan PT. Setia Kawan Makmur Sejahtera Tulungagung. Dapat diartikan bahwa semakin baik penerapan praktik TQM yang dijalankan oleh perusahaan akan meningkatkan hasil kinerja karyawan.

Selain itu, hasil pengujian outer loading juga menunjukkan bahwa keberhasilan penerapan praktik TQM pada perusahaan lebih didominasi oleh adanya kerjasama dalam tim. Sedangkan pencapaian kinerja karyawan lebih diutamakan pada kualitas hasil kerja. Kondisi ini mengindikasikan bahwa dengan adanya tim yang solid, maka penyelesaian pekerjaan dapat dilakukan dengan lebih baik dan efektif sesuai dengan standar kualitas yang ditetapkan.

\section{Pengaruh Total Quality Manajement (TQM) terhadap kinerja karyawan dengan dimediasi kepuasan kerja}

Infrastruktur manajemen kualitas terkait dengan faktor sumber daya manusia yang menjalankan manajemen kualitas, sehingga manusia sebagai faktor utama dalam implementasi TQM akan menjadi faktor penting dalam pencapaian kinerja keuangan maupun kinerja perusahaan secara keseluruhan.

Hasil penelitian menunjukkan bahwa praktik TQM berdampak penting terhadap kinerja karyawan melalui kepuasan kerja karyawan PT. Setia Kawan Makmur Sejahtera Tulungagung. Namun, dampak mediasi kepuasan kerja karyawan tersebut diketahui bersifat mediasi sebagian (partial mediation). Dari sini, dapat dikatakan bahwa kepuasan kerja dapat menjembatani pengaruh antara praktik TQM terhadap kinerja karyawan, akan tetapi tanpa adanya kepuasan kerja pada dasarnya penerapan praktik TQM yang efektif juga mempunyai pengaruh yang kuat dalam meningkatkan kinerja karyawan.

Sebagaimana diketahui bahwa salah satu kendala yang dihadapi oleh perusahaan saat ini adalah tingginya tingkat turnover karyawan. Permasalahan tersebut mengindikasikan masih 
rendahnya kepuasan kerja yang dirasakan oleh karyawan, sehingga menyebabkan banyaknya karyawan yang memutuskan untuk berhenti bekerja. Sementara, hasil penelitian menunjukkan bahwa praktik TQM mempunyai dampak penting terhadap kepuasan karyawan, yang artinya semakin baik penerapan praktik TQM yang dijalankan oleh perusahaan akan meningkatkan kepuasan kerja karyawan. Dari sini, dapat dikatakan bahwa untuk meningkatkan kepuasan kerja karyawan, perusahaan perlu melakukan perbaikan atas implementasi praktik TQM yang selama ini sudah dijalankan. Secara riil, saat ini perusahaan lebih menekankan implementasi TQM pada aspek pelanggan, sehingga sebagian program yang dilaksanakan oleh perusahaan lebih difokuskan pada perbaikan kualitas produk atau pelayanan sesuai dengan keinginan pelanggan. Sedangkan aspek-aspek TQM yang lain masih belum bisa berjalan secara efektif, terutama aspek kerjasama tim, yang justru hal ini dianggap paling penting oleh karyawan.

Selain itu, diketahui pula bahwa terjadi ketidakseimbangan antara jumlah pekerja dengan beban kerja yang ditanggung masingmasing pekerja, sehingga hal ini memicu terciptanya perasaan tidak puas dari karyawan yang pada akhirnya akan menyebabkan kualitas hasil kerja yang menurun. Dari sini, perusahaan perlu melakukan upaya-upaya untuk meningkatkan kepuasan kerja karyawan. Berdasarkan kondisi dilapangan, karyawan sudah merasa puas dalam hal supervisi dan kesempatan promosi yang diberikan oleh perusahaan, namun masih kurang puas dalam hal hubungan dengan rekan kerja dan besarnya gaji yang mereka terima. Sebagaimana diketahui bahwa kerjasama tim merupakan hal penting yang paling diinginkan oleh karyawan, sehingga apabila kerjasama tim dapat berjalan dengan baik dan efektif maka diharapkan hubungan antara karyawan dan sesama rekan kerjanya juga bisa menjadi lebih baik. Di sisi lain, tingkat gaji yang relatif rendah juga menjadi pemicu kurang puasnya karyawan, ditambah dengan beban kerja yang cukup besar dan bahkan tumpang tindih sehingga pemberlakuan standar gaji saat ini dirasa kurang seimbang.

\section{Hasil}

Berdasarkan pembahasan hasil penelitian yang telah diuraikan sebelumnya, dapat diketahui bahwa implementasi praktik TQM pada dasarnya dapat mempengaruhi secara langsung, baik terhadap kepuasan kerja maupun kinerja karyawan. Selain itu, temuan penelitian juga mengungkapkan bahwa dampak langsung implementasi TQM terhadap kinerja karyawan jauh lebih besar dibandingkan dengan dampak tidak langsungnya melalui kepuasan kerja karyawan. Kondisi ini mengindikasikan bahwa meskipun kepuasan kerja mampu menjembatani pengaruh praktik TQM terhadap kinerja karyawan, namun ketika perusahaan berhasil melakukan perbaikan atas implementasi TQM secara menyeluruh dan berkelanjutan, maka tanpa adanya kepuasan kerja sekalipun hal ini sudah dapat meningkatkan kinerja karyawan secara langsung.

Sebagaimana diketahui bahwa dalam implementasi TQM, kerjasama tim merupakan aspek yang dinilai cukup penting oleh karyawan dalam mendorong pencapaian kinerja mereka. Dari sini, karyawan membutuhkan suatu sarana untuk membangun efektivitas teamwork dalam pelaksanaan setiap tugas atau pekerjaannya. Kenyataan yang menunjukkan bahwa perusahaan lebih fokus pada pelanggan dibandingkan pada aspek kerjasama tim menyebabkan adanya kesenjangan kepentingan diantara perusahaan dan karyawan, sehingga hal ini dapat menjadi koreksi perusahaan dalam melakukan evaluasi terhadap implementasi TQM yang telah diterapkan sebelumnya. Selain itu, aspek lain yang juga dinilai cukup penting oleh karyawan adalah budaya organisasi. Sebagaimana diungkapkan oleh Parncharoen (2005) bahwa penerapan manajemen mutu organisasi pada hakekatnya merupakan program perubahan organisasi yang memerlukan transformasi budaya organisasi, proses, dan keyakinan. Jadi, apabila penerapan sistem manajemen mutu dapat merubah orientasi budaya organisasi menuju budaya kualitas, maka sesuai dengan pendapat Hardjosoedarmo (2005) hal ini akan dapat meningkatkan kinerja karyawan dan pada akhirnya meningkatkan kinerja perusahaan.

Di sisi lain, peran kepuasan kerja juga dapat memberikan pengaruh yang kuat terhadap kinerja karyawan, yang artinya apabila aspekaspek yang mendorong perasaan puas karyawan dapat terpenuhi atau dapat dirasakan sepenuhnya, maka karyawan akan lebih termotivasi untuk meningkatkan kualitas kerjanya. Dalam hal ini, peran supervisi dari atasan dinilai paling penting dalam proses penyelesaian kerja karyawan, sehingga saat ini perusahaan lebih concern pada kegiatan 
supervisi sebagai bagian dari pelaksanaan monitoring terhadap pencapaian produktivitas dan kinerja karyawan. Selain itu, aspek lain dari kepuasan kerja yang juga dinilai cukup penting dalam mendorong pencapaian kinerja karyawan adalah hubungan dengan rekan kerja. Sebagaimana dijelaskan sebelumnya bahwa kerjasama tim sangat menentukan kualitas kerja karyawan, maka dari sini karyawan perlu membangun hubungan yang baik dengan sesama rekan kerjanya. Kebutuhan inilah yang masih kurang bisa dirasakan oleh karyawan, sehingga menciptakan gap diantara mereka serta menimbulkan ketidaknyamanan dalam bekerja.

Dari keseluruhan hasil temuan penelitian, dapat disimpulkan bahwa efektivitas kerjasama tim (sebagai bagian penting dalam implementasi praktik TQM) akan menciptakan hubungan baik diantara para karyawan, sehingga dapat mendorong perasaan puas karyawan dan pada akhirnya meningkatkan kualitas kinerja mereka.

\section{Implikasi Penelitian Implikasi Teoritis} lain:

Implikasi teoritis dari penelitian ini antara

1. Penelitian ini mendukung konsep teori manajemen operasional yang digunakan sebagai dasar teori mengenai dampak implementasi TQM terhadap pencapaian tujuan perusahaan.

2. Penelitian ini membangun sebuah model integrasi dalam melihat dampak dari implementasi praktik TQM terhadap kinerja karyawn melalui peran kepuasan kerja yang dirasakan oleh karyawan.

3. Hasil temuan penelitian menunjukkan bahwa kepuasan kerja mampu memberikan peran mediasi sebagian pada pengaruh TQM terhadap kinerja karyawan. Hal ini mengindikasikan fenomena baru, bahwa meskipun tanpa kepuasan kerja, kinerja karyawan dapat ditingkatkan secara optimal melalui implementasi praktik TQM yang efektif dan komprehensif.

\section{Implikasi Praktis} lain:

Implikasi praktis dari penelitian ini antara

1. Hasil penelitian ini memberikan penegasan terhadap pentingnya praktik TQM yang diterapkan oleh suatu perusahaan, khususnya pada perusahaan manufaktur, dalam mendorong kepuasan kerja serta kinerja karyawan. Kerjasama tim menjadi hal yang paling penting yang dipertimbangkan dan dipikirkan oleh karyawan jika dibandingkan aspek lain seperti budaya organisasi, fokus pada pelanggan, kepercayaan organisasi, dan rewards. Oleh karena itu, pihak manajemen perusahaan, khususnya manajer produksi perlu melakukan upaya-upaya dalam meningkatkan kerjasama tim dalam pelaksanaan pekerjaan, baik untuk mempertahankan hubungan baik diantara para karyawan maupun untuk memperbaiki kualitas kerja karyawan.

2. Hasil penelitian ini menunjukkan bahwa tingkat kepuasan kerja yang dirasakan oleh karyawan memberikan implikasi pada peningkatan kinerja karyawan tersebut. Dari beberapa aspek yang dapat mendorong kepuasan kerja karyawan, diketahui bahwa aspek supervisi menjadi hal yang paling penting bagi karyawan jika dibandingkan dengan aspek-aspek yang lain seperti rekan kerja, kesempatan promosi, dan gaji. Oleh karena itu, pihak manajemen perusahaan perlu memperbaiki sistem supervisi yang dijalankan, terutama dengan meningkatkan keterlibatan karyawan dalam perencanaan maupun pelaksanaan program strategis perusahaan, sehingga dapat meningkatkan perasaan puas karyawan terhadap pekerjaannya.

3. Hasil penelitian menunjukkan bahwa kepuasan karyawan belum mampu memberikan peran mediasi secara penuh, melainkan hanya secara parsial (sebagian). Kondisi ini mengindikasikan bahwa kepuasan kerja yang dirasakan karyawan masih rendah atau belum sepenuhnya. Kurangnya perasaan puas terutama dirasakan pada aspek hubungan dengan rekan kerja dan aspek gaji. Dari sini, perusahaan perlu melakukan evaluasi secara seksama, terutama dalam pemerataan beban pekerjaan sehingga tidak terjadi overload atau overlapp pekerjaan yang nantinya dapat memicu konflik dan memunculkan persepsi diskriminasi diantara para karyawan.

\section{Keterbatasan Penelitian}

Penelitian ini dilakukan dengan mengumpulkan data melalui survey para Karyawan PT. Setia Kawan Makmur Sejahtera Tulungagung. Tujuan penelitian secara umum adalah melihat dampak dari TQM, kepuasan kerja, dan kinerja karyawan. Penelitian ini tidak terlepas dari adanya keterbatasan-keterbatasan 
yang dimiliki yang menyebabkan kurang sempurnanya hasil penelitian. Beberapa keterbatasan tersebut antara lain:

1. Penelitian ini hanya bersifat cross-sectional (dilakukan pada satu waktu saja), dan tidak bersifat longitudinal, sehingga tidak membandingkan persepsi dari para pekerja pada rentang waktu yang berkelanjutan, yang mungkin dapat memberikan informasi atau gambaran tambahan mengenai fenomena dalam penelitian.

2. Penelitian ini hanya mengambil sampel dari karyawan PT. Setia Kawan Makmur Sejahtera Tulungagung, sehingga generalisasi hasil hanya dikhususkan pada lingkup PT. Setia Kawan Makmur Sejahtera Tulungagung.

3. Konsep yang digunakan dan diukur dalam penelitian ini menggunakan rating penilaian diri sendiri (self assessment), sehingga subyektivitas responden mungkin masih melekat, meskipun hal ini tidak mengurangi keabsahan data yang diperoleh dalam penelitian.

\section{DAFTAR PUSTAKA}

Akdere, M. 2009. A Multi-Level Examination of Quality-Focused Human Resource Practices and Firm Performance: Evidence from the US Healthcare Industry. International Journal of Human Resource Management, 20 (9): 945-964.

Akrani, Gaurav. 2011. What is Production Management? Meaning Definition Importance. $\mathrm{http} / /$ kalyancity.blogspot.co.id/2011/12/what-isproduction-management-meaning.html. Diakses tanggal 02 Januari 2017.

Alhudri, Said dan Meyzi Heriyanto. 2015. Pengaruh Penerapan Total Quality Management (TQM) Terhadap Kinerja Karyawan Pada PT. PLN (Persero) Ranting Bangkinang. Jom FISIP, 2 (2): $1-14$.

Al-Nasser, A., Yusoff, R. dan Islam, R. 2013. Relationship between Hard Total Quality Management Practices and Organization Performance in Municipalities. American Journal of Applied Sciences, 10 (10): 1214-1223.

Alshery, W. Bin Rashed, Fais Bin Ahmad, and Abdullah Kaid Al-Swidi. 2015. The Moderating Effect of Role Ambiguity on the Relationship of Job Satisfaction,
Training and Leadership with Employee Performance. International Journal of Business Administration, 6 (2).

Alsughayir, Abdulrahman. 2014. Does Practicing Total Quality Management Affect Employee Job Satisfaction in Saudi Arabian Organizations?. European Journal of Business and Management, 6 (3): 169-175.

Al-Shobaki, Salman D., Rami H. Fouad, and Adnan Al-Bashir. 2010. The Implementation of Total Quality Management (TQM) for The Banking Sector in Jordan. Jordan Journal of Mechanical and Industrial Engineering, 4 (2): 304-313.

Ardiansyah, Dimas Okta. 2016. Pengaruh Komunikasi Terhadap Kinerja Karyawan Dengan Dimediasi Oleh Kepuasan Kerja (Studi Pada Bagian Produksi Pabrik Kertas PT. Setia Kawan Makmur Sejahtera Tulungagung). Jurnal Bisnis dan Manajemen, 3 (1).

Arikunto, Suharsimi. 2010. Prosedur Penelitian : Suatu Pendekatan Praktis. Edisi Revisi. Rineka Cipta. Jakarta.

Aydin, Bulent. 2010. A Research Analysis on Employee Satisfaction in Terms of Organizational Culture and Spiritual Leadership. International Journal Business and Management, 4 (3).

Brunetto, Yvonne and Farr-Wharton. 2002. The Impact of Supervisor Communication on The Job Satisfaction of Early Career Police Officer IFSAM. Conference Gold Coasts.

Chang, C., Chiu, C., dan Chen, C. 2010. The Effect of TQM Practices on Employee Satisfaction and Loyalty in Government. The TQM Magazine, 21 (12): 1299-1314.

Crossman, Alf and Bassem Abou-Zaki. 2003. Job Satisfaction and Employee Performance pf Lebanese Banking Staff. Journal of Managerial Psychology, 18 (4): 368-376.

Culbertson, S. 2009. Do Satisfied Employees Mean Satisfied Customers?. Academy of Management Perspectives, 23 (1): 7677.

Dizgah, Morad Rezaei. 2012. Relationship Between Job Satisfaction and Employee Job Performance in Guilan Public Sector. Text Road Publication, 2 (2): 1735-1741. 
Enny, W. Mahmudah. 2015. Effect of ISO 9002008 QMS, Total Quality Management and Work Environment on Job Satisfaction and Employee Performance at PT. Mount Dreams Indonesia in Gresik. The International Journal of Business and Management, 3 (4): 369375.

Finasari, Dian Maya. 2006. Pengaruh Penerapan Konsep Total Quality Management terhadap Kinerja Karyawan Melalui Kepuasan Kerja (Studi Kasus Pada Monthly Labour PT. Sampoerna Printpack Sukorejo). Skripsi (Tidak dipublikasikan). Fakultas Ekonomi, Universitas Negeri Malang.

Flynn, B. B., Schroeder, R.G., dan Sakakibara, S. 1994. A Framework for Quality Management Research and An Associated Measurement Instrument. Journal of Operations Management, 11 (4): 339-366.

Garcia-Bernal, Javier, Ana Gargallo-Castel, Mercedes Marzo-Navarro, dan Pilar Rivera-Torres. 2005. Job satisfaction: Empirical Evidence of Gender Differences. Women in Management Review, 20 (4): 279-288.

Gaspersz, V. 2005.Total Quality Management. PT. Gramedia Pustaka Umum, Jakarta..

Ghozali, Imam. 2005. Aplikasi Analisis Multivariate dengan program SPSS, Badan. Penerbit Universitas Diponegoro, Semarang.

Ghozali, Imam. 2016. Aplikasi Analisis Multivariate Dengan Program IBM SPSS 23. BP Universitas Diponogoro. Semarang.

Ghozali, Imam dan Hengky Latan. 2012. Partial Least Squares : Konsep, Teknik dan Aplikasi Menggunakan Program SmartPLS 2.0 M3. Badan Penerbit Universitas Diponegoro, Semarang.

Govindan, S. and Ahmad, Z.A. 2003. Managing Manufacturing Professional's Job Satisfaction Via Human Resource Management Practices. The Fifth Asian Academy of Management Conference: Conference Proceedings, 2: 513-22. Pahang, Malaysia.

Greenberg, Jerald dan Robert A. Baron. 2003. Behaviour in Organizations, Understanding and Managing The Human Side of Work. Third Edition.
Allin and Bacon. Massachuscets Boston.

Grunberg L, Moore SY, dan Greenberg E. 2001. Differences in Psychological and Physical Health Among Layoff Survivors: The Effect of Layoff Contact. J. Occup. Health Psychol, 6 (1): 15-25.

Hair, J. F., Black W. C., Babin B. J., and Anderson R. E. 2010. Multivariate Data Analysis. 7th Edition. New Jersey: Pearson Education Inc.

Handoko, T. Hani. 2013. Manajemen Edisi 2. BPFE. Yogyakarta.

Hardjosoedarmo, S. 2005. Total Quality Management. Andi. Yogyakarta.

Hasibuan, Melayu SP. 2011. Manajemen Sumber Daya Manusia. Edisi Revisi. Bumi Aksara.

Heizen, Jay and Render Barry. 2004. Operation Management. Edisi tujuh. Salemba Empat. Jakarta.

Humphrey, S. E., Nahrgang J. D., and Morgeson, F.P. 2007. Integrating Motivational, Social, and Contextual Work Design Features: A MetaAnalytic Summary and Theoretical Extension of the Work Design Literature. Journal of Applied Psychology, 92 (5): 1332-1356.

Ismunawan. 2010. Penerapan Penilaian Kinerja dan Sistem Pengukuran. Jurnal Graduasi, 24: 27 - 29.

Jabnoun, N. and K. Sedrani. 2005. TQM, Culture, and Performance in UAE Manufacturing Firms. Quality Management Journal. 12 (4): 8-20.

Jex, Steve M. 2002. Organizational Psychology: a Scientist-Practitioner Approach. Jon Wiley \& Sons. New York.

Juana, Ni Putu P., I Gde Adnyana S., dan Desak Ketut S. 2016. Pengaruh Implementasi Sistem Manajemen Mutu ISO 9001:2008 terhadap Kinerja Pegawai dengan Mediasi Kepuasan Kerja. Jurnal Buletin Studi Ekonomi, 21 (1): 92 - 101.

Kaynak, Hale. 2003. The Relationship Between Total Quality Management Practices And Their Effects on Firm Performance. Journal of Operations Management, 21: 405-435.

Khan, A. Hussain, Muhammad M. Nawaz, Muhammad Aleem, and Wasim Hamed. 2012. Impact of Job Satisfaction on Employee Performance: An Empirical 
Study of Autonomous Medical Institutions. African Journal of Business Management, 6 (7): 2697-2705.

Krawjeski, J., P. Ullrank. 2004. Total Quality Management Strategy and Analysis, Fifth Edition, Addison-Wesley Publising Company Inc.

Luthans, Fred. 2006. Perilaku organisasi. Edisi 10. Andi. Yogyakarta.

Luthans, Fred. 2011. Organizational Behavior: An Evidence - Based approach. The McGrow-Hill Companies, Inc. New York.

Luburić, Radoica. 2014. Total Quality Management as a Paradigm of Business Success. Journal of Central Banking Theory and Practice,. 3 (1): 59-80.

Malik, E.M., Danish R.Q., dan Munir Y. 2012. The Impact of Pay and Promotion on Job Satisfaction: Evidence form Pakistan. American Journal of Economics, 6 (9): 6-9.

Mangkunegara, Anwar Prabu. 2012. Evaluasi Kinerja SDM. Cetakan keenam. Refika Aditama. Bandung.

Milovanovic, Alex. 2016. Introduction to Operations Management. http://www.insidecareers.co.uk/careeradvice/introduction-to-operationsmanagement/. Diakses tanggal 02 Januari 2017.

Moeljono, D. 2003. Budaya Korporat dan Keunggulan Korporasi. PT. Elex Media Komputindo. Jakarta.

Mofoluwake, Ajayi P. and Abimbola H. Oluremi. 2013. Job Satisfaction, Organizational Stress and Employee Performance: A Study of NAPIMS. Ife Psychologia, 21 (2): 75-90.

Ozduru, Cihan Irfan. 2015. On the role of Operations Management in an organization.

https://www.linkedin.com/pulse/roleoperations-management-organizationirfan ozduru. Diakses tanggal 02 Januari 2017.

Ooi, Keng-Boon, Abu Bakar N., Arumugam V., Vellapan L., and Kim Yin Loke A. 2007. Does TQM Influence Employees' Job Satisfaction? An Empirical Case Analysis. International Journal of Quality and Reliability Management, 24 (1): 62-77.

Ooi, Keng-Boon, Arumugam V., Teh PL, and Chong AYL. 2008. TQM Practices and
Its Association with Production Workers. Ind. Management Data System, 108 (7): 909-927.

Ooi, K.B., Lin, B., Tan, B.I., and Chong, A.Y.L. 2011. Are TQM Practices Supporting Customer Satisfaction and Service Quality. Journal of Service Marketing, 25 (6): 410-419.

Parncharoen, C.; A. Girardi, L. Entrekin. 2005. The Impact of Cultural Values on The Succesful Implementation of Total Quality Management: A Comparison between the Australian and Thai Models. http://blake.montclair.edu. pp. 597-605.

Poernomo, Eddy. 2006. Pengaruh Kreativitas dan Kerjasama Tim terhadap Kinerja Manajer pada PT. Jesslyn K Cakes Cabang Surabaya. Jurnal Ilmu-Ilmu Ekonomi, 6 (2): 102-108.

Prajogo D.I. dan A.S. Sohal. 2006. The Relationship Between Organization Strategy, Total Quality Management (TQM), and Organization PerformanceThe Mediating Role of TQM. European Journal of Operational Research, 168: 35-50.

Purcell, J. and Kinnie, N. 2007. HRM and Business Performance, in Boxall, P., Purcell, J. and Wright, R. (Eds.), Oxford Handbook of Human Resource Management, Oxford University Press, Oxford, pp. 533-52.

Purwanto, Henry, 2010. Pengaruh Iklim Organisasi dan Budaya Organisasi Terhadap Kinerja Karyawan dan Kepuasan Kerja Karyawan Strata III PT. Perkebunan Nusantara (PTPN) XII. Tesis (Tidak dipublikasikan). Universitas Jember.

Pushpakumari. 2008. The Impact of Job Statisfaction on Job Performance: An Empirical Analysis. Journal of Cities Forum, 1 (9): 89-105.

Putri, Rinella. 2009. Mengenal 7 Tools Utama Dalam Quality Control. http://vibizmanagement.com/column/in dex/category/quality management/1 640/10. Diakses tanggal 20 Oktober 2016.

Robbins, Stephen P. 2006. Perilaku Organisasi. PT Indeks. Kelompok Gramedia. Jakarta. 
Robbins, Stephen P. dan Timothy A. Judge. 2013. Perilaku Organisasi. Penerbit Salemba Empat. Jakarta.

Samsir. 2014. Implementasi Total Quality Management terhadap Kepuasan Kerja Karyawan. Jurnal Sosial Ekonomi Pembangunan, 4 (11): 136-151.

Schroeder, R. G., K. Linderman, dan D. Zhang. 2005. Evolution of Quality: First Fifty Issues of Production and Operations Management. Production and Operations Management, 14 (4): 468481.

Sousa-Pouza A, Sousa-Pouza AA. 2000. Wellbeing at Work: A Crossnational Analysis of The Levels and Determinants Of Job Satisfaction. $J$. Socio-Econ., 29: 517-38.

Sugiyono. 2011. Metode Penelitian Pendidikan (Pendekatan Kuantitatif, Kualitatif, dan $R \& D)$. Alfabeta. Bandung.

Sugiyono. 2013. Statistika untuk Penelitian. Alfabeta. Bandung.

Sukwadi, Ronald. 2012. Analisis Pengaruh Implementasi Gugus Kendali Mutu Terhadap Kinerja dan Kepuasan Kerja Karyawan Menggunakan Model Persamaan Struktural. INASEA, 13 (2): 132-140.

Syaiin, S. 2008. Pengaruh Kepuasan Kerja Terhadap Kinerja Pegawai Klinik Spesialis Bestari Medan. Tesis (Tidak dipublikasikan). Pascasarjana Universitas Sumatera, Medan.

Therese, A Joire. 2007. Total Quality Management and Performance. JQRM, 24 (6): 617-627.

Tika, Moh. Pabundu. 2006. Budaya Organisasi dan Peningkatan Kinerja Perusahaan. PT. Bumi Aksara. Jakarta.

Tinuke, et al. 2012. Correlates of Total Quality Management and Employee Performance: An Empirical Study of a Manufacturing Company in Nigeria. 2 (6).

Tjiptono, F., dan A. Diana. 2001. Total Quality Management. Valentine. Yogyakarta.

Tjiptono, F. dan A. Diana. 2003. Total Quality Management. Edisi Revisi. Andi. Yogyakarta.

Tjiptono, Fandy dan Anastasia Diana. 2007. Total Quality Management. Edisi Revisi. Penerbit Andi. Yogyakarta.

Valmohammadi, C. and Khodapanahi, M. 2011. The Impact of ISO 9001:2000
Implementation on Employees' Job Satisfaction: A Case study. International Journal of Academic Research, 3 (1): 601-609.

Wright, P.M., Gardner, T.M., and Moynihan, L.M. 2003. The Impact of HR Practices on The Performance of Business. Human Resource Management Journal, 13: 21-36.

Yuan Hu, Hsiu, et al. 2011. A Study of Customer Satisfaction, Customer Loyalty, and Quality Attributes in Taiwan's Medical Service Industry. African Journal of Business Management, 5 (1): 187-195.

Yue, Jing-Wen, Keng-Boon Ooi, and Choong Chee Keong. (2011). The Relationship Between People Related Total Quality Management (TQM) Practices, Job Satisfaction and Turnover Intention: A Literature Review and Proposed Conceptual Model. African Journal of Business Management. 5 (5): 66326639.

Zehir, Cemal. 2010. Investigating The Effects of Innovation And Employee Performance on The Relationship Between Total Quality Management Practices And Firm Performance: An Empirical Study of Turkish firms. 13-26.

Zhang, Z.H., Waszink, Ab. and Wijngaard, J. 2000. An instrument for measuring TQM implementation for Chinese manufacturing companies. International Journal of Quality \& Reliability Management, 17 (7): 730735. 